Volume 8 No. 2, Juli-Desember 2021

P-ISSN: 2406-808X // E-ISSN: 2550-0686

https://journal.iainlangsa.ac.id/index.php/ikhtibar

https://doi.org/10.32505/ikhtibar.v8i2.626

\title{
Strategi Kepala Sekolah Dalam Mengatasi Permasalahan Pembelajaran Online di Masa Pandemi COVID 19
}

\author{
Lukman A. \\ IAIN Curup, Bengkulu, Indonesia \\ lukman.asha@iaincurup.ac.id
}

\begin{abstract}
The purpose of this research was to gain an understanding of the principal's strategies as a manager in overcoming problems that arouse during the implementation of online learning at SDIT al-Kahfi in Lebong Regency, Bengkulu Province. This study applied a qualitative approach, with data gathered through observation of learning activities via Whastapp groups and interviews with informants such as school principals, PAI teachers, students, and parents. Following the collection of data, an analysis was performed using Miles' et al theory in order to find conclusive answers. The principal's strategies to solve the problems of online learning at SDIT al-Kahfi Lebong fell into the following: sending teachers to attend seminars or getting engaged into the training of information technology and learning with peers, providing guidance or training for children in groups or individually, providing counseling and conducting counseling meetings with students' parents about the importance of android in the learning process, and giving an understanding of the importance of parental cooperation in supervising their children's learning from home.
\end{abstract}

Keywords: Principal's Strategy, Online Learning

\begin{abstract}
Abstrak
Penelitian ini bertujuan menemukan gambaran tentang strategi kepala sekolah sebagai manajer dalam mengatasi problem yang terjadi dalam pelaksanaan pembelajaran online di SDIT al-Kahfi Kabupaten Lebong Propinsi Bengkulu. Penelitian dilakukan dengan pendekatan kualitatif, data dikumpulkan melalui observasi kegiatan pembelajaran melalui grup Whataap dan wawancara kepada informan seperti kepala sekolah, guru PAI, siswa dan orang tua. Setelah data terkumpul selanjutnya dilakukan analisis dengan menggunakan teori Miles dkk sehingga menemukan jawaban dalam bentuk simpulan. Simpulan penelitian ini adalah strategi kepala sekolah untuk menyelesaikan permasalahan pembelajaran daring di SDIT al-Kahfi Lebong adalah: mengutus guru untuk mengikuti seminar atau pelatihan tentang teknologi informasi dan belajar pada teman sebaya, memberi bimbingan atau pendampingan anak secara kelompok atau individual, memberi penyuluhan dan mengadakan pertemuan dengan wali murid mengenai pentingnya penggunaan android dalam proses pembelajaran
\end{abstract}


dan memberikan pengertian tentang pentingnya kerjasama orang tua dalam mengawasi putra-putrinya belajar dari rumah.

\section{Kata Kunci: Strategi Kepala Sekolah, Pembelajaran Online}

\section{Pendahuluan}

Saat ini Corona masih menjadi pembicaraan yang hangat. Di belahan bumi manapun, corona masih mendominasi ruang publik. Dalam waktu singkat saja, namanya menjadi trending topik, dibicarakan di sana-sini, dan diberitakan secara masif di media cetak maupun elektronik(Elisvi et al., 2020; Uyun \& Warsah, 2021b; Warsah, 2021). Severe Acute Respiratory Syndrome Coronavirus 2 (SARS-COV-2) yang lebih dikenal dengan nama virus corona adalah jenis baru dari coronavirus yang menyebabkan penyakit menular ke manusia, terlebih lagi telah ditemukannya varian baru yang lebih ganas dari varian-varian sebelumnya yaitu varian Delta dari India (Hartono \& Yusuf, 2021; Riley et al., 2021).

Covid-19 adalah penyakit menular yang disebabkan oleh jenis coronavirus yang baru ditemukan. Walaupun lebih banyak menyerang ke lansia, virus ini sebenarnya bisa juga menyerang siapa saja, mulai dari bayi, anak-anak, hingga orang dewasa. Virus corona ini bisa menyebabkan ganguan ringan pada sistem pernapasan, infeksi paru-paru yang berat, hingga kematian. Corona Virus Disease 2019 (COVID19) pertama kali ditemukan di kota Wuhan, China pada akhir Desember 2019. Virus ini menular sangat cepat dan telah menyebar hampir ke semua negara, termasuk Indonesia, hanya dalam waktu beberapa bulan saja. Sehingga WHO pada tanggal 11 Maret 2020 menetapkan wabah ini sebagai pandemi global (Elisvi et al., 2020; Meliza et al., 2020).

Hal tersebut membuat beberapa negara menetapkan kebijakan untuk memberlakukan lockdown dalam rangka mencegah penyebaran virus corona. Di Indonesia sendiri, pernah diberlakukan kebijakan Pembatasan Sosial Berskala Besar (PSBB) dan saat ini juga Kembali diberlakukan Pemberlakuan Pembatasan Kegiatan Masyarakat level 4 (PPKM) untuk menekan penyebaran virus ini. Karena Indonesia sedang melakukan pembatasan tersebut, maka semua kegiatan yang dilakukan di luar rumah harus dihentikan sampai pandemi ini mereda.

Sampai saat pemerintah pusat maupun pemerintah daerah memutuskan menerapkan kebijakan untuk meliburkan siswa sekolah tatap muka dan menerapkan metode belajar dengan sistem daring (dalam jaringan) atau online. Kebijakan pemerintah ini mulai efektif diberlakukan di beberapa wilayah provinsi di Indonesia pada hari Senin, 16 Maret 2020 yang juga diikuti oleh wilayah-wilayah provinsi lainnya sampai saat ini. Tentu hal menjadi problem tersendiri bagi beberapa sekolah di tiap-tiap daerah. Sekolah-sekolah tersebut tidak siap dengan sistem pembelajaran daring, dimana membutuhkan media pembelajaran seperti handphone, laptop, atau komputer (Tamara et al., 2020).

Sistem pembelajaran dilaksanakan melalui perangkat personal computer (PC) atau laptop yang terhubung dengan koneksi jaringan internet. Guru dapat melakukan pembelajaran bersama diwaktu yang sama menggunakan grup di media sosial seperti WhatsApp (WA), telegram, instagram, aplikasi zoom ataupun media lainnya sebagai media pembelajaran. Dengan demikian, guru dapat memastikan siswa mengikuti pembelajaran dalam waktu yang bersamaan, meskipun di tempat yang berbeda (Atsani, 2020; Herlina, 2020).

Semua sektor merasakan dampak corona. Dunia pendidikan salah satunya. Dilihat dari kejadian sekitar yang sedang terjadi, baik siswa maupun orangtua siswa 


\section{Al-Ikhtibar: Jurnal Ilmu Pendidikan, Volume 8 No. 2, Juli-Desember 2021}

yang tidak memiliki handphone untuk menunjang kegiatan pembelajaran daring ini merasa kebingungan, sehingga pihak sekolah ikut mencari solusi untuk mengantisipasi hal tersebut (Ambarsari, 2021; Ramadhani, 2020; Tanjung, 2021). Beberapa siswa yang tidak memiliki handphone melakukan pembelajaran secara berkelompok, sehingga mereka melakukan aktivitas pembelajaran pun bersama. Mulai belajar melalui videocall yang dihubungkan dengan guru yang bersangkutan, diberi pertanyaan satu persatu, hingga mengapsen melalui VoiceNote yang tersedia di WhatsApp. Materi-materinya pun diberikan dalam bentuk video yang berdurasi kurang dari 2 menit.

Penelitian Fathurahman (2020) menegaskan bahwa peran pemerintah khususnya bidang pendidikan pada masa krisis yang disebabkan oleh wabah covid-19 sangat diperlukan sebagai acuan dasar dalam pelaksanaan proses pembelajaran. Diharapkan akan ada banyak strategi yang dilakukan dan pendekatan-pendekatan melalui peran pemerintah daerah khususnya pendidikan, untuk tetap melaksanakan proses aktifitas belajar di setiap satuan pendidikan yang terdapat pada pemerintahan daerah tersebut. Berdasarkan Surat Edaran Mendikbud No 3 Tahun 2020 tentang "langkah pencegahan covid-19 pada satuan pendidikan", dan Surat Edaran Mendikbud No 4 Tahun 2020 tentang " pelaksanaan pendidikan pada masa covid 19". Bahwa selama wabah covid-19 ini berlangsung siswa diminta untuk melaksanakan proses Belajar Dari Rumah (BDR), dan guru juga melakukan pengajaran dari rumah. Sehingga harus dilakukan proses perubahan dan melakukan penyesuaian yang sangat cepat dalam kondisi ini (Amini \& Ginting, 2020).

World Bank menyebutkan bahwa pandemi covid-19 ini sekarang mengancam dan berpotensi besar membuat hasil pendidikan lebih buruk. Pandemi telah memiliki dampak besar pada pendidikan dengan menutup sekolah hampir di mana-mana di dunia ini. Tetapi adalah mungkin untuk mengatasi guncangan ini, dan untuk mengubah krisis menjadi peluang (Murfi et al., 2020; Sudika, 2020). Langkah pertama adalah untuk berhasil mengatasi penutupan sekolah, dengan melindungi kesehatan dan keselamatan dan melakukan apa yang mereka bisa untuk mencegah siswa kehilangan pembelajaran menggunakan pembelajaran jarak jauh. Pada saat yang sama, negara-negara perlu mulai merencanakan pembukaan kembali sekolah. Itu berarti mencegah putus sekolah, memastikan kondisi sekolah yang sehat, dan menggunakan teknik baru untuk mempromosikan pemulihan belajar cepat di bidangbidang utama begitu siswa kembali ke sekolah (Khairuddin, 2020; Sudika, 2020).

Sekolah sebagai Lembaga yang diberi Amanah untuk mencerdaskan generi bangsa harus tetap berjalan di tengah kondisi yang serba sulit ini dan Kepala sekolah merupakan seseorang yang berada di garda terdepan dalam upaya mencerdaskan bangsa (Erdiyanto et al., 2020; Rozi et al., 2020). Kepala sekolah merupakan ujung tombak dalam keberhasilan maju atau tidaknya suatu satuan pendidikan yang ia pimpin. Kepala sekolah memikul tanggung jawab terhadap kenyamanan dan ketertiban lingkungan sekolah serta warga sekolahnya. Rasa aman dan nyaman ini harus dirasakan oleh guru, siswa dan orangtua. Termasuk dalam hal keamanan dan kenyamanan di masa tanggap darurat pandemi covid-19 (Manurung \& Sibuea, 2021; Nadeak \& Juwita, 2020; Wiguna, 2021).

Kepala sekolah mempunyai peran penting dalam menjaga kualitas proses pembelajaran yang akan berlangsung dalam mendukung, mendorong, monitoring, dan memfasilitasi (Jamali, 2019). Kepala sekolah bertanggung jawab di masa covid-19 ini yaitu menjamin kualitas belajar murid di rumah melalui pelaksanaan kepemimpinan, fungsi manajemen dan. pengelolaan pemSbelajaran di masa wabah covid-19. Kepala 


\section{Al-Ikhtibar: Jurnal IImu Pendidikan, Volume 8 No. 2, Juli-Desember 2021}

sekolah diharapkan memiliki peran yang inovatif dalam menyusun berbagai perencanaan untuk menunjang proses pembelajaran bagi peserta didik dan kesiapan pendidik dalam melaksanakan pembelajaran (Warsah \& Nuzuar, 2018). Kebijakan belajar dari rumah selama pandemi Covid-19 telah berlangsung sejak Maret 2020 (Lestari \& Gunawan, 2020).

Kepala sekolah dituntut untuk dapat lebih profesional dengan kemampuan manajerial dalam menhadapi masa krisis yang disebabkan oleh pandemi covid-19, seingga penelitian ini akan berupaya melakukan analisis terhadap peran kepala sekolah dari sisi manajemen krisis di masa pandemi covid-19 dalam ruang lingkup otonomi pendidikan di SDIT Al-Kahfi Kabupaten Lebong. Hal ini sangat menarik untuk dikaji untuk dicari beberapa pemikiran yang dapat menyumbangkan saran dan strategi dalam memperkuat proses pendidikan yang berlangsung di tengah pandemi covid-19 saat ini. Pengajaran berlangsung dengan cara online. Proses ini berjalan pada skala yang belum pernah terukur dan teruji sebab belum pernah terjadi sebelumnya.

\section{Landasan Teori}

\section{Pembelajaran Efektif}

Menurut Saefudin dan Berdiati dalam Tariga (2019) belajar dapat dimaknai sebagai suatu proses yang menunjukan adanya perubahan yang sifatnya positif sehingga pada tahap akhirnya akan didapat ketrampilan, kecakapan, dan pengetahuan baru yang didapat dari akumulasi pengalaman dan pembelajaran. Definisi ini menegaskan bahwa belajar adalah aktivitas yang terjadi pada setiap manusia sejak lahir. Proses belajar dapat terjadi karena adanya unsur kesengajaan ataupun tidak disengaja. Belajar adalah mengubah kelakuan anak mengenai pembentukan pribadi anak.

Hasil yang diharapkan dari proses belajar bukan hanya bersifat pengetahuan akan tetapi juga sikap, pemahaman, minat dan penghargaan norma-norma meliputi seluruh pribadi anak (Angdreani et al., 2020; Warsah, 2018a). Pembelajaran merupakan suatu serangkaian rencana kegiatan yang termasuk di dalamnya penggunaan metode dan pemanfaatan berbagai sumber daya atau kekuatan dalam suatu pembelajaran dan disusun untuk mencapai suatu tujuan pembelajaran. Efektivitas merupakan unsur pokok untuk mencapai tujuan sasaran yang telah ditentukan. Efektivitas adalah suatu ukuran yang menyatakan seberapa jauh target (kuantitas, kualitas dan waktu) yang telah tercapai (Nasution, 2016). Dengan demikian efektif lebih mengarah kepada pencapaian sasaran/tujuan.

Pembelajaran yang efektif adalah apabila kegiatan mengajar dapat mencapai tujuan sesuai pada perencanaan awal. Pembelajaran dikatakan efektif ketika peserta didik dapat menyerap materi pelajaran dan efisien (Pane \& Dasopang, 2017). Dalam setiap pembelajaran guru maupun pendidik seharusnya memiliki perencanaan awal secara tertulis dalam bentuk RPP (Rencana Pelaksanaan Pembelajaran). Seorang guru memiliki tugas tidak hanya merencanakan, guru juga harus memantau apakah kegiatan pembelajaran sudah sesuai dengan tujuan yang direncanakan sehingga siswa dapat memahami materi dengan baik. Bahkan guru juga harus memanfaatkan waktu dengan baik sehingga pembelajaran menjadi efisien sehingga pembelajaran dapat dikatakan efektif.

Media Pembelajaran juga sangat diperlukan oleh seorang guru. Media adalah perantara dari sumber informasi ke penerima informasi, contohnya televisi dan handphone. Alat tersebut merupakan media perantara apabila digunakan untuk menyalurkan informasi yang akan disampaikan Secara teknis (Abi Hamid et al., 2020). Media pembelajaran berfungsi sebagai sumber belajar yakni sebagai penyalur 
dan penghubung terhadap peserta didik. Tidak jarang guru enggan memperhatikan tujuan pembelajaran yang telah dirumuskan atau kompetensi dasar yang telah diterapkan dalam standart isi. Guru hanya berorientasi pada pemberian materi ajar sehingga guru tidak mampu melakukan pembelajaran untuk ketercapaian kompetensi peserta didik.

Pembelajaran aktif, inovatif, kreatif, efektif dan menyenangkan (PAIKEM) dalam dunia pendidikan sangat penting. PAIKEM menghendaki peran guru yang maksimal sebagai perancang pembelajaran untuk memotivasi dalam mengemas pembelajaran (Cholid, 2021). Penguasaan guru untuk mengelola kelas dengan baik akan berhasil guna mencapai tujuan pembelajaran. Faktor-faktor yang mempengaruhi belajar efektif sebagai berikut (Rahmawati \& Suryadi, 2019):

\section{a. Faktor internal}

1) Kesehatan: Sehat berarti dalam keadaan baik segenap badan beserta bagianbagian tubuh terbebas dari penyakit. Proses belajar seseorang akan terganggu jika kesehatan seseorang tersebut terganggu.

2) Cacat Tubuh: Keadaan cacat tubuh juga akan mempengaruhi proses belajar, karena jika siswa yang cacat belajarnya juga akan terganggu.

3) Intelegensi: Intelegensi adalah kecakapan untuk menghadapi dan menyesuaikan diri ke dalam situasi yang baru dengan cepat dan efektif.

4) Minat: Minat adalah kecenderungan yang tetap untuk memperhatikan kegiatan belajar. Minat besar pengaruhnya terhadap belajar karena apabila pelajaran yang dipelajari tidak sesuai dengan minat siswa maka siswa tidak akan belajar dengan sebaik-baiknya.

5) Kesiapan: Kesiapan adalah kesediaan untuk memberi reaksi atau bereaksi. Kesiapan ini perlu diperhatikan dalam proses belajar karena jika siswa belajar dan sudah ada kesiapan maka hasil belajarnya akan lebih baik.

\section{b. Faktor eksernal}

1) Suasana rumah: Agar anak dapat belajar dengan baik perlu diciptakan suasana rumah yang tenang dan tenteram.

2) Relasi antar anggota keluarga: Kelancaran belajar serta keberhasilan anak harus ada relasi yang baik di dalam keluarga. Jadi hubungan yang baik adalah hubungan yang penuh pengertian dan kasih sayang disertai dengan bimbingan untuk menyukseskan belajar anak itu sendiri.

Pembelajaran dianggap efektif jika siswa secara aktif melaksanakan tahapantahapan pembelajaran. Dari segi hasil dianggap efektif jika tujuan pembelajaran dikuasai siswa secara tuntas.

\section{Problematika Pembelajaran}

Menurut Rosihuddin problematika pembelajaran adalah permasalahan yang mengganggu, menghambat, atau mempersulit bahkan mengakibatkan kegagalan dalam mencapai tujuan pembelajaran (Sekha, 2020). Adanya faktor problematika pembelajaran adalah sebagai berikut:

a. Faktor Pendekatan Pembelajaran

Bermula dari problematika pembelajaran yang muncul di masyarakat ini adanya masalah lingkungan sekitar, orang tua, dan pendidikan. Tetapi selama ini pembelajaran hanya menekankan pada perilaku namun banyak siswa yang tidak bisa menghargai perbedaan. Oleh karena itu, Peserta didik harus diperlakukan dengan hatihati dan penuh kesabaran karena, peserta didik adalah insan yang identitasnya adalah manusia yang untuk didik. 
b. Perubahan Kurikulum

Dalam dunia pendidikan sering sekali terjadi perubahan kurikulum hal inilah yang menyebabkan sering membuat bingung peserta didik. Contohnya jika siswa sudah mulai mengerti dengan kurikulum KTSP dan secara cepat berkala akan diganti dengan kurikulum 2013. Kurikulum merupakan pegangan guru yang akan diajarkan kepada peserta didik untuk arah pembelajaran.

c. Faktor Kompetensi Guru

Profesionalisme guru ini sangat menunjang keberhasilan siswa dalam belajar di sekolah jika seorang guru mempunyai kompetensi yang baik maka akan tercipta pula para peserta didik yang pemahamannya di sekolah dapat diterapkan di rumah. Selanjutnya jika seorang guru mempunyai profesionalisme dan pemahaman agama yang baik maka akan mudah sekali menjelaskan kepada siswa tentang materi keagamaan. Materi keagamaan sangatlah penting dalam pendidikan konvensional agar kelak menjadi bekal siswa terhadap perubahan teknologi. Sekolah konvensional juga membentuk kepribadian siswa menjadi lebih berakhlak mulia dan ahli ibadah.

Problematika pembelajaran di atas dapat ditelusuri dari jalannya proses dasar pembelajaran dan sebagai sebuah proses pembelajaran dihadapkan pada beragam permasalahan/problematika. Masalah interaksi belajar mengajar merupakan masalah yang kompleks karena melibatkan berbagai faktor yang saling terkait satu sama lain. Sekian banyak faktor yang mempengaruhi proses dan hasil interaksi belajar mengajar terdapat dua faktor yang sangat menentukan yaitu faktor guru sebagai subjek pembelajaran dan peserta didik sebagai objek pembelajaran.

\section{Pembelajaran Daring}

Menurut Sanjaya pembelajaran daring adalah pembelajaran yang memanfaatkan teknologi atau jaringan internet dalam proses pembelajaran. Perkembangan teknologi secara cepat telah membawa peradaban ini menuju ke revolusi industri 4.0 (Sanjaya, 2020). Saat ini berada di zaman dimana teknologi dan internet mendukung berbagai lini kehidupan. Wabah covid-19 mendadak menyerang setiap orang dan semua siswa yang tadinya tawar-menawar dengan pemanfaatan teknologi dipaksa untuk menggunakanya. Perubahan drastis ini tentunya tidak mudah diterima bagi sebagian pihak namun untuk saat ini hanya teknologi dengan pembelajaran dari rumahlah yang mampu menjadi jembatan untuk tetap berlangsungnya transfer ilmu.

Kartikawati dalam Dewi (2020) mengatakan pembelajaran daring di rumah tetap dapat dilaksanakan. Dalam hal pelaksanaan belajar dari rumah guru meminta orang tua dan kakak siswa sebagai narasumber yang langkah-langkahnya telah diberikan melalui grup. Untuk laporan pelakasanaan berupa video dan foto harus diposting melalui grup. Berbeda dengan Setiawan dalam Suhartiningsih (Suhartiningsih, 2021) menyampaikan beberapa metode pembelajaran secara daring yang telah ditetapkan yaitu pembelajaran melalui rumah yang dibagikan melalui media sosial.

Menurut Purnomo Dewi (2020) pembelajaran jarak jauh dengan menerapkan metode pemberian tugas secara daring bagi siswa melalui grup dipandang efektif dalam kondisi darurat karena adanya virus corona seperti ini. Banyak guru yang menggunakan cara-cara beragam belajar di rumah ada yang menggunakan ceramah online, ada yang tetapa menagajar di kelas tetapi divideokan dan kemudian dikirim ke aplikasi siswa.

Wabah covid-19 semakin mereba Indonesia tidak luput dari wabah tersebut. Sekolah, Universitas mau tidak mau suka atau tidak suka harus bergerak, turut untuk mengatasi keadaan. Sekolah-sekolah mulai dikosongkan secara massal. Belajar dari 


\section{Al-Ikhtibar: Jurnal Ilmu Pendidikan, Volume 8 No. 2, Juli-Desember 2021}

rumah menjadi sebuah kepastian untuk memutus rantai covid-19 (Suhartiningsih, 2021). Dalam situasi seperti ini semua unsur perlu beradaptasi dengan cepat. Teknologi Informasi (IT) dan komunikasi tidak lagi gagap dengan pemanfaatan teknologi dalam proses belajar mengajar. Pembelajaran melalui audio-visual digital atau menggunakan internet sudah biasa dilakukan sehari-hari, di rumah (Suhartiningsih, 2021).

Dalam pelaksanaan daring ini seorang guru hendaknya mengetahui langkahlangkah pembelajaran daring yaitu: a) Guru harus memanfaatkan waktu dan memberi tugas via Google Classroom, pre-test atau pemberian tugas dengan pemanfaatan Google Drive. Hal ini mutlak harus dilakukan untuk mentransfer pengetahuan kepada peserta didik; b) Guru seorang guru harus menyajikan pembelajaran yang terencana dan efektif dalam keterbatasan waktu; c) Dalam kegiatan akhir pembelajaran daring ini hendaknya seorang guru memberikan penguatan karakter/motivasi kepada siswa yang disampaikan guru kepada wali murid atau siswa agar menjadi siswa yang tangguh dan siap dalam kondisi apapun seperti yang terjadi saat pandemi corona ini (Suhartiningsih, 2021).

Pembelajaran daring adalah pembelajaran yang dilakukan dirumah atau bisa dimanapun dan kapanpun. Ketika timbul situasi yang darurat seperti ini WHO menyarankan untuk belajar dari rumah. Indonesia spontan menggunakan model pembelajaran ini karena sangat darurat dan belum diketahui sampai kapan akan terjadi pembelajaran daring seperti ini. Pembelajaran daring atau pembelajaran online menjadi satu-satunya model pembelajaran yang digunakan di Indonesia (Suhartiningsih, 2021).

Maraknya penularan covid-19 ini membuat dunia menjadi resah termasuk Indonesia. Social distancing diterapkan oleh pemerintah dalam rangka membatasi interaksi masyarakat dari keramaian dan terhindar dari virus ini (Suhartiningsih, 2021). Adapun masalah atau kendala yang mempengaruhi pembelajaran daring adalah:

a Tidak adanya jaringan data/kuota. Tidak adanya data atau kuota menjadi kendala dalam proses pembelajaran daring.

b Kurangnya pemahaman Tentang IT. Perkembangan teknologi saat ini dirasa penting karena ilmu teknologi akan membantu proses belajar mengajar seseorang tanpa harus bertemu langsung secara tatap muka. Namun tidak semua masyarakat mengerti tentang teknologi karena sebagian orang tua siswa terutama yang berada di pedesaan tidak memiliki alat komunikasi seperti handphone. Hal ini yang menjadi kendala pembelajaran daring.

c Tidak adanya jaringan atau signal: Jaringan internet bisa tersambung dari handphone atau alat komunikasi dikarenakan adanya sinyal, jika dalam keadaan tidak adanya sinyal maka akan mengakses sesuatu dalam internet.

Tidak boleh ada kata tidak siap dalam menghadapi situasi darurat seperti ini. Kreativitas dan komunikasi menjadi dua hal yang sangat penting dalam memastikan agar tujuan pembelajaran tercapai (Yessi, 2021). Pembelajaran daring ini tentunya ada banyak kelebihan dan kekurangan sebagai berikut:

a. Kekurangan: 1) Sulit untuk mengontrol mana siswa yang serius mengikuti pelajaran dan mana yang tidak; 2) Pembelajaran lebih minim karena tidak dimungkinkan adanya interaksi langsung dengan siswa; 3) Akan kesulitan bagi mereka yang tinggal di lokasi yang infrastruktur komunikasinya masih kurang baik dan tewntu aksan kesulitan mengakses internet; 4) Tidak semua siswa memiliki dan mampu mengakses internet. 
a. Kelebihan: 1) Waktu dan tempat lebih efektif karena siswa bisa langsung mengikuti proses belajar dari rumah; 2) Menumbuhkan kesadaran pada siswa bahwa internet dapat digunakan untuk hal-hal yang produktif; 3) Siswa dilatih untuk lebih menguasi teknologi informasi yang terus berkembang.

\section{Metode Penelitian}

Penelitian ini menggunakan pendekatan kualitatif untuk memperoleh informasi mengenai problematika pembelajaran daring dan cara kepala sekolah mengatasinya (studi di SDIT Al-Kahfi Lebong) (Prsetyo \& Jannah, 2019). Pemilihan sekolah tersebut berdasarkan pada beberapa alas an antara lain, jarak antara peneliti dan sekolah yang cukup terjangkau, kepala sekolah dan guru bersikap terbuka dan sekolah tersebut telah menerapkan belajar online. Informan kunci penelitian ini yaitu kepala sekolah, satu orang guru PAI, peserta beberapa siswa dan orang tua sebagai pewakilan masing-masing informan.

Data Penelitian ini dikumpulkan melalui wawancara dan observasi (Robinson et al., 2016). Setelah data terkumpul, selanjutnya dilakukan analisis dengan menggunakan pendekatan Miles, Huberman dan Saldana. Data yang sudah tersedia dari hasil wawancara dan pengamatan yang sudah dituliskan dalam catatan lapangan selanjutnya dianalisis dengan dukungan teori-teori yang sudah ada, sehingga dapat ditemukan jawaban dari pertanyaan-pertanyaan penelitian yang telah dirumuskan pada pendahuluan dalam bentuk beberapa hasil penelitian. Dengan demikian, Analisis data kualitatif bersifat induktif, yaitu suatu analisis berdasarkan data yang diperoleh, selanjutnya dikembangkan menjadi hipotesis (Miles et al., 2014) .

Analisis data dimaksud terdapat beberapa alur kegiatan yang terjadi secara bersamaan, yaitu: Reduksi Data: Mereduksi adalah merangkum dan memilih hal yang penting. Dengan demikian data yang direduksi akan memberi gambaran yang jelas tentang strategi kepala sekolah SDIT Al-Kahfi Lebong dalam mengatasi permasalahan pembelajaran online di masa pandemi; Penyajian Data: Peneliti menyajikan data yang sudah mendapatkan informasi yang tersusun dan memberikan kesimpulan dan pengambilan tindakan, memudahkan peneliti untuk mengambil tindakan berdasarkan informasi yang telah didapat seputar strategi kepala sekolah SDIT Al-Kahfi Lebong dalam mengatasi permasalahan pembelajaran online di masa pandemic; Penarikan Kesimpulan atau Verifikasi: Setelah penyajian data selesai selanjutnya peneliti mengambil kesimpulan untuk dapat mengetahui jawaban tentang strategi kepala sekolah SDIT Al-Kahfi Lebong dalam mengatasi permasalahan pembelajaran online di masa pandemi.

\section{Hasil dan Pembahasan \\ 1. Hasil Penelitian \\ a. Pelaksanaan Pembelajaran Daring di SDIT Al-Kahfi Lebong}

Gambaran tentang pembelajaran online di SDIT Al-Kahfi ini akan dideskripsikan melalui data hasil wawancara dan obsevasi sebagai berikut, menurut pernyataan dari guru SDIT Al-Kahfi Lebong bahwa "Pembelajaran daring saat ini sulit, karena banyak siswa yang orang tuanya belum memiliki android. Bahkan untuk membagikan Lembar Kerja ke siswa kita juga kadang datang ke rumah masingmasing siswa" (Wawancara, Melin Bien Siska, 24 Desember 2020). Namun jika ditanyakan kepada siswa terkaik kesan mereka belajar dari rumah dan berdasarkan hasil observasi di lapangan, ditemukan bahwa mereka merasakan belajar dari rumah 
itu tidaklah se enak Ketika belajar seperti sebelumnya, bahkan tidak sedikit dari mereka mengalami kesulitan dalam memahami materi yang diberikan oleh guru.

Salah seorang siswa menyatakan "Kalau belajar dari rumah tidak enak dan karena kalau kurang paham, harus tanya sama siapa? Kalau di kelas enak banyak temen dan guru. Jadi kalau saya tidak paham bisa bertanya kepada ibu guru." (Wawancara, Avika Anjania, 24 Desember 2020). Siswa tersebut merasakan bahwa proses pembelajaran efektif dan lebih menyenangkan adalah pembelajaran lansgung di sekolah jika dibanding pembelajaran dari rumah. Lebih lanjut Avika mengatakan “ kalua belajar di sekolahan saya akan kembali berkumpul dengan teman-teman, kalau di rumah sepi jadi malas mengerjakan tugas dari guru, sementara tiap hari selalu diberi tugas oleh guru jadi saya melas sekali menyelesaikannya". (Wawancara, Avika Anjania, 24 Desember 2020).

Terkait dengan tugas yang dimaksud oleh siswa di atas, peneliti melakukan pengamatan pembelajaran daring melalui media grup Whatapp, ditemukan bahwa proses pemberian tugas dari guru yang diberikan kepada siswa ini melalui grup orang tua siswa, dan dalam grup ini guru memberikan tugas untuk mengerjakan LKS halaman 30" tanpa memberikan penjelasan secara rinci dan hanya menginstruksikan kepada siswa akar terlebih dahulu membaca teks dalam buku paket yang telah tersedia di rumah (Observasi, 24 Desember 2020, pukul 10.00 - 10.30).

Menurut guru PAI SDIT Al-Kahfi menyatakan bahwa "Pembelajaran daring ini saya juga membuat RPP ya sama saja mbak dengan pembelajaran efektif di kelas, tanpa RPP saya juga ga bisa mengetahui indikator yang harus dicapai siswa" (Wawancara, Melin Bien Siska, 24 Desember 2020). Lebih lanjut guru mengatakan pelaksanaan pembelajaran daring menggunakan metode penugasan dan media handphone, "Metode yang saya gunakan ya metode penugasan mbak, dan saya memberikan penugasan melalui android. "Pada pelajaran Aqidah akhlak, proses evaluasi untuk siswa yaitu menghafal surat pendek dengan video, setelah itu saya minta mengirim ke saya atau bisa japri dan yang tidak punya android datang ke sekolah langsung saya minta membacakan surah pendek. "Saya memberikan tugas dari hari senin-sampai sabtu mbak, hari sabtu anak-anak mengumpulkan tugas dan mengirimkan ke whatsapp saya." (Wawancara, Melin Bien Siska, 24 Desember 2020).

Ibu Melin juga menjelaskan bahwa "Jika ada beberapa siswa saya kelas VI yang nilai di bawah KKM 70 saya minta saya beri tugas tambahan ya itu buat remidi dan memperbaiki nilai." (Wawancara, Melin Bien Siska, 24 Desember 2020). Memang masih ditemukan oleh guru masih ada seorang siswa yang orang tuanya mempunyai android tetapi tidak bisa menggunakannya., menurutnya "Setiap hari ada siswa saya yang bertanya tugas datang ke sekolah itu setiap hari, dia juga mengumpulkan tugas dengan datang ke sekolah."(Wawancara, Melin Bien Siska, 24 Desember 2020).

Guru menyatakan bahwa Perbedaan tingkat pemahaman siswa satu dengan yang lain berbeda yang ini diungkapkannya bahwa "Pemahaman peserta didik berbeda mbak, ada yang langsung bisa dan benar saat mengerjakan tugas, tetapi ada juga yang benar-benar tidak paham sama sekali." (Wawancara, Melin Bien Siska, 24 Desember 2020). Dalam melakukan penguatan dan pendalaman materi, guru berupaya melakukan Langkah konkret seperti pada setiap pemberian materi di grup selalu membuka termin pertanyaan terkait penugasan, "Saya selaku guru kelas VI dalam setiap pemberian materi melalui grup saya selalu berusaha dan tidak lupa untuk 
membuka termin pertanyaan kepada wali murid atau siswa yang belum paham terkait dengan materi atau tugas”. (Wawancara, Melin Bien Siska, 24 Desember 2020)

\section{b. Problematika Pembelajaran Daring KelasVI di SDIT Al-Kahfi Lebong}

Rewi Arisandi selaku kepala sekolah mengatakan bahwa: "Ya saya sebagai kepala sekolah harus bekerja maksimal dalam situasi ini. Karena terkadang ada bahkan banyak orang tua yang belum menggunakan telephone pintar. Jadi ya kita yang datang kerumah siswa tersebut untuk memberikan buku. kita ini kan di desa jadi mayoritas uang mereka cukup untuk membiayai kehidupan sehari-hari daripada untuk membeli handphone dan kuota juga sekarang mahal mbak." (Wawancara, Rewi Arisandi, 28 Desember 2020).

Lebih lanjut Kepala sekolah mengatakan proses pembelajaran daring sangat berat, berikut pernyataanya: "Adanya wabah ini Menurut saya proses pembelajaran daring ini lumayan berat mbak, karena saya sebagai kepala sekolah harus memikirkan bagaimana proses pembelajaran bisa tetap berjalan. Meskipun berat ya tetep dijalani saja, kalau bukan kita yang memberi ilmu kepada siswa siapa lagi? Saat ini komunikasi sangat penting meskipun tidak semua menggunakan android tapi siswa disini sering datang kerumah temen yang orang tuanya tidak punya alat komunikasi, jadi bareng-bareng kalau mengumpulkan tugas dari guru." (Wawancara, Rewi Arisandi, 28 Desember 2020)

Menurut ibu Melin kendala yang paing banyak ditemukan di lapangan adalah orang tua belum siap membantu anaknya belajar dari rumah karena gagap teknologi "Banyak orang tua siswa disini yang benar-benar tidak bisa menggunakan android padahal punya android. Kata salah seorang orang tua siswa itu karena alasan android ribet mbak" (Wawancara, Melin Bien Siska, 24 Desember 2020). Kepala sekolah mengatakan bahwa "Lingkungan mendukung menggunakan android tetapi di pedesaan ekonomi juga mempengaruhi karena biaya operasional tinggi sedangkan pemasukan sedikit. Banyak orang tua yang sibuk dengan urusannya sendiri dan apalagi mbak pembelajaran di rumah sudah lama jadi orang tua ada yang mengeluh saya tidak telaten menemani anak saya belajar". (Wawancara, Rewi Arisandi, 28 Desember 2020)

\section{c. Strategi Kepala Sekolah untuk Mengatasi Problematika Pembelajaran Daring di SDIT Al-Kahfi Lebong}

Kepala sekolah mengatakan solusi yang dapat menyelesaikan permasalahan yang dihadapi dalam proses pembelajaran daring di SDIT Al-Kahfi Lebong. "Saya meminta kepada siswa yang tidak mempunyai android untuk langsung datang ke sekolah karena semua guru disini standby di sekolah termasuk juga guru kelas VI". ( Wawancara, Rewi Arisandi, , 28 Desember 2020).

Ibu Melin selaku guru kelas VI mengatakan bahwa: "Ya saya minta ke siswa untuk join atau bergabung bersama teman dan bisa datang ke sekolah untuk mengumpulkan tugas. (Wawancara, Melin Bien Siska, 24 Desember 2020). Selanjutnya, peran orang tua dan kerjasama orang tua saat pembelajaran daring sangat penting. Menurut ibu Melin "Saya minta tolong dengan datang ke rumah dan memberitahu kepada orang tua agar bisa mengawasi dan membantu pelaksaaan pembelajaran daring ini, Saya juga terus memberikan semangat agar terus belajar kepada siswa saya tidak membedakan mana siswa yang pintar atau belum pintar, sama-sama saya berikan motivasi dan semangat kepada mereka dan saat saya datang ke rumah siswa saya bilang sama orang tuanya tolong dampingi anak-anak ibu-bapak untuk terus belajar". (Wawancara, Melin Bien Siska, 24 Desember 2020) 


\section{Pembahasan}

Setelah data diketahui sebagaimana yang disajikan pada fakta-fakta di atas, maka sebagai tindakan lebih lanjut dari penelitian ini yaitu menganalisis data yang terkumpul menggunakan metode deskriptif kualitatif secara terperinci. Dalam usaha memanfaatkan media pembelajaran secara efektif seringkali guru dan siswa mengalami berbagai hambatan baik yang menyangkut tentang dirinya maupun yang di luar dirinya.

Berdasarkan hasil temuan sebelumnya, dapat diketahui bahwa hanya guru saja mengalami kendala dalam proses pembelajaran daring namun setelah dilakukan cross check dengan membandingkan temuan dengan sumber lain, ditemukan fakta bahwa tidak hanya guru yang mengalami kendala, tetapi juga murid. Pada proses pembelajaran daring kelas VI di SDIT Al-Kahfi Lebong kelas VI di SDIT Al-Kahfi Lebong berjalan baik seperti proses pembelajaran di dalam kelas, dan sudah baik terlihat guru memberikan materi dan penugasan. Tidak hanya pemberian materi dan penugasan pada saat guru akan memberikan tugas di grup ke pada siswa guru selalu rutin memberikan kata-kata atau ucapan semangat dan salam kepada siswa agar tetap semangat dalam pembelajaran dari rumah ini. Guru kelas VI di SDIT Al-Kahfi Lebong menentukan media belajar yang sesuai dengan kondisi siswa agar belajar di rumah dapat berjalan secara efektif. Media yang dipilih guru adalah menggunakan android melaui grup. Sementara dalam pemberian materi dan penugasan setiap hari senin-sabtu melalui grup dan guru membuka termin pertanyaan kepada siswa atau wali murid yang belum jelas dengan pemberian materi atau tugas yang diberikan oleh guru dan guru tersebut langsung menjawab pertanyaan melalui grup kelas IV.

Dalam setiap pemberian tugas apabila ada siswa yang belum mencapai KKM (Kriteria Ketuntasan Mininal) yang telah ditentukan oleh sekolah yakni 70, maka guru kelas memberikan proses evaluasi untuk memperbaiki nilai yang kurang tersebut. Proses evaluasi yang diberikan oleh guru yaitu dengan cara pemberian tugas tambahan, tugas tambahan diberikan kepada siswa untuk memperbaiki nilai yang kurang. Oleh karena itu, dalam proses evaluasi guru memberikan tugas tambahan yang bisa dikumpulkan langsung ke sekolah karena guru kelas standby setiap hari pada jam kerja. Menurut Undang-Undang No.20/2003 tentang Sistem Pendidikan Nasional Pasal 58 ayat (1) evaluasi peserta didik dilakukan oleh pendidik untuk memantau proses, kemajuan dan perbaikan hasil belajar peserta didik (Kumaidi, 2018). Pelaksanaan pembelajaran daring di SDIT Al Kahfi Lebong ini sebelum guru mengirim tugas atau materi ke grup, guru mempersiapkan materi/bahan ajar yang akan diunggah/disebarkan kepada siswa melalui grup selanjutnya dalam proses pembelajaran daring di rumah, guru menggunakan alternatif dengan grup.

Siswa mempelajari materi mata pelajaran dan mengerjakan tugas yang diberikan oleh guru dan melakukan monitoring pelaksanaan pembelajaran daring. Dalam pembelajaran dari rumah ini guru kelas memberikan penjelasan apabila ada pertanyaan dari siswa dan selanjutnya siswa diminta mempelajari bahan/materi pelajaran yang diunggah oleh guru dan siswa dapat melakukan diskusi dengan guru kelas melalui media online jika masih ada hal yang kurang jelas dari materi yang diberikan oleh guru (Salim, 2021). Di akhir pembelajaran dari rumah/daring guru memberikan tugas untuk selanjutnya dikerjakan oleh siswa. Pengumpulan tugas dengan cara siswa langsung datang ke sekolah dan pada pagi hari, Setelah pengumpulan tugasa selesai siswa kembali ke rumah masing-masing, untuk mengetahui hasil belajar siswa, guru memberikan soal-soal tertulis untuk dikerjakan oleh siswa (Salim, 2021). 
Problematika pembelajaran adalah permasalahan yang mengganggu dan menghambat atau mempersulit proses pencapaian tujuan pembelajaran dan menghambat jalannya pembelajaran. Pada proses pembelajaran daring di SDIT AlKahfi Lebong belum berjalan dengan baik karena menghadapi masalah atau problem yang begitu kompleks. Diantara masalah atau problem yang muncul pada proses pembelajaran daring kelas VI di SDIT Al-Kahfi Lebong adalah:

\section{a. Masalah kompetensi guru}

Kompetensi adalah pengetahuan, keterampilan dan perilaku yang harus dimiliki dan dikuasai oleh seorang guru dalam melaksanakan tugas mengajarnya. Di SDIT Al Kahfi Lebong sendiri masih ada guru yang mengalami kesulitan dalam menggunakan dan memanfaatkan pembelajaran berbasis teknologi, hal ini disebabkan karena guru kurang keterampilan dan pengetahuan atau gaptek (gagap teknologi) akan pentingnya mengoperasionalkan media pembelajaran berbasis teknologi informasi. Kompetensi guru di SDIT Al-Kahfi Lebong masih jauh dari harapan dan dapat dikatakan belum berada dalam kondisi yang memadai terutama dalam memanfaatkan dan membuat pembelajaran yang berbasis teknologi.

Hal ini menyebabkan siswa menjadi pasif dan merasa jenuh saat proses pembelajaran, karena masih ada guru yang masih bingung dalam menggunakan teknologi. Padahal sebagai seorang guru ia dituntut dan seharusnya mempunyai kompetensi dasar dalam penggunaan teknologi informasi. Sudah menjadi tuntutan di dalam kurikulum bahwa seorang guru harus memiliki kompetensi yang memadai termasuk dalam menggunakan media pembelajaran. Di lapangan ditemukan hasil bahwa terdapat guru yang belum bisa mengoperasionalkan alat teknologi informasi seperti kesulitan dalam memilih media pembelajaran dan kurang familiar dengan media berbasis teknologi informasi. Betapa canggihnya alat pembelajaran jika guru tidak terampil maka hal itu akan sia-sia (Prajodi \& Afrila, 2021). Jadi, kompetensi guru merupakan kemampuan yang harus dimiliki oleh seorang guru.

\section{b. Perbedaaan tingkat pemahaman peserta didik}

Para siswa di SDIT Al-Kahfi Lebong memiliki karakter dan pemahaman yang berbeda-beda mengenai materi atau penugasan yang diberikan oleh guru. Karena anak yang masih di tingkatan sekolah dasar menjadi sulit untuk menangkap materi yang bersifat abstrak. Apalagi dalam proses pembelajaran daring saat ini, dan guru langsung memberikan tugas tanpa penjelasan materi terlebih dahulu. Setiap individu memiliki tingkatan kecerdasan yang berbeda-beda, proses pembelajaran daring yang telah berlangsung lama membuat siswa di SDIT Al-Kahfi Lebong menjadi kesulitan untuk menerima pelajaran dari guru.

Menurut Susanto dalam (Fatmawati, 2021) pemahaman dapat diartikan sebagai kemampuan untuk menyerap arti dari materi atau bahan yang dipelajari, pemahaman ini adalah seberapa besar siswa mampu menyerap, dan memahami palajaran yang diberikan oleh guru kepada siswa, atau sejauh mana siswa dapat memahami serta mengerti apa yang ia baca, dan yang dilihat. Kadang dalam proses pembelajaran guru sudah merasa maksimal tetapi respons yang diberikan siswa juga relatif pasif. Hal ini menjadi salah satu tantangan berat yang harus dilewati guru dalam proses pembelajaran.

\section{c. Orang tua yang tidak memiliki android}

Di SDIT Al-Kahfi Lebong dalam proses pembelajaran daring ini dilakukan dengan kurangnya komunikasi terhadap peserta didik itu sendiri karena banyak orang tua siswa yang tidak memiliki android/alat komunikasi yang canggih. Dalam hal ini 
android sangat penting demi terwujudnya proses pembelajaran daring. Di sisi lain, orang tua yang mayoritas orang pedesaan sangat sulit menggunakan alat komunikasi canggih. Sistem pembelajaran daring ketika alat daring yakni android yang tidak dimiliki siswa membuat sistem pembelajaran jarak jauh menjadi terganggu atau tidak berjalan lancar. Orang tua wali siswa tidak menggunakan android sebagai pemanfaatan teknologi untuk tercapainya proses pembelajaran daring (Salim, 2021).

\section{d. Kurangnya kerjasama orang tua dengan siswa}

Para orang tua di SDIT Al Kahfi Lebong cenderung tidak menemani putraputrinya belajar di rumah dikarenakan dengan berbagai alasan yakni alasan karena sibuk bekerja, sibuk mengurus rumah dan sibuk dengan hal yang lain. Orang tua membiarkan putra-putinya belajar dan mengerjakan tugas sendiri tanpa ditemani oleh bapak-ibu mereka. Bahkan setelah dilakukan wawancara dengan guru kelas, banyak orang tua yang tidak telaten mendampingi putra-putrinya belajar di rumah selama pandemi ini. Hal ini membuat hak seorang anak untuk belajar menjadi tidak terkontrol karena banyak yang malah bermain sepeda dan bermain layang-layang bersama teman yang lain.

\section{e. Keterbatasan sarana prasarana}

Sarana dan prasarana adalah segenap proses pengadaan agar mendukung tercapainya tujuan pendidikan secara tepat dan tepat sasaran. Barnawi dan Arifin dalam (Fatimah et al., 2021) menjelaskan bahwa sarana pendidikan adalah mencakup semua peralatan dan perlengkapan secara langsung sedangkan prasarana pendidikan mencakup semua peralatan dan perlengkapan yang secara tidak langsung menunjang proses pendidikan. Di SDIT Al-Kahfi Lebong sendiri kurangnya sarana yang dibutuhkan oleh peserta didik.

Berdasarkan beberapa permasalahan atau problematika yang telah diuraikan di atas, terdapat pula solusi atau upaya yang harus dilakukan oleh kepala sekolah selaku penanggungjawab pelaksanaan pembelajaran di sekolah untuk mengatasi problematika tersebut antara lain yaitu:

\section{1) Solusi mengatasi kompetensi guru}

Dalam upaya untuk mengatasi kompetensi guru, sebenarnya dari pihak guru ataupun pihak sekolah SDIT Al-Kahfi Lebong sudah melakukan beberapa usaha atau upaya untuk mengatasinya. Diantaranya dengan belajar dengan guru yang lain dan mengikuti pelatihan di forum-forum tertentu dan mengikuti seminar. Semua upaya atau usaha untuk mengatasi permasalahan di atas dipandang tepat dan baik. Tapi hal itu ada kekurangannya terkadang guru yang mengikuti pelatihan dan seminar itu malah justru asik ngobrol sendiri. Akan tetapi semua kembali pada pribadi masingmasing dengan alasan faktor usia atau sudah tua tidak mampu untuk mengoperasionalkan komputer atau teknologi informasi merupakan suatu kesalahan.

Solusi untuk mengatasi kekurangan di atas adalah kepala sekolah di SDIT Al Kahfi Lebong bertanya kepada guru yang serius untuk mengikuti seminar dan pelatihan agar nantinya guru mempunyai ketrampilan untuk menggunakan teknologi informasi. Oleh karena itu dalam menyelenggarakan pembelajaran guru menggunakan teknologi sebagai media (Nahdi \& Jatisunda, 2020).

\section{2) Solusi mengatasi perbedaaan tingkat pemahaman peserta didik}

Perbedaan individual berkaitan dengan "psikologi pribadi" yang membuat cara menerima suatu pelajaran dan dalam berpikir (Uyun \& Warsah, 2021a). Untuk mengatasi beraneka-macam anak didik dalam proses pembelajaran daring, guru dan pihak sekolah telah mencari solusi agar anak didik memiliki pemahaman yang sama 
yaitu dengan cara guru tetap memperhatikan perbedaan yang ada dalam muridmuridnya dengan cara memotivasi agar terus tetap belajar dalam kondisi apapun antara lain: pertama, guru memberikan pendampingan pada anak didik baik secara berkelompok atau individual (Warsah \& Uyun, 2019). Cara yang ditempuh dalam usaha untuk mengatasi masalah ini di atas dipandang tepat, namun guru tidak harus memberikan pelayanan khusus antar individu.

\section{3) Solusi mengatasi orang tua yang tidak memiliki android}

Menurut Budiman dalam (Prajodi \& Afrila, 2021; Salim, 2021) perkembangan teknologi informasi yang semakin pesat di era globalisasi ini tidak bisa dihindari lagi pengaruhnya terhadap dunia pendidikan, tuntutan global menuntut dunia pendidikan untuk selalu dan senantiasa menyesuaikan perkembangan teknologi untuk peningkatan mutu pendidikan. Kepala sekolah di SDIT Al Kahfi Lebong maupun guru memberikan solusi terkait orang tua yang tidak memiliki android, yaitu dengan cara apabila ada orang tua atau siswa yang tidak masuk group salah seorang siswa memberikan informasi terkait penugasan dan bisa datang langsung dan bertanya kepada guru dengan datang ke sekolah karena guru di SDIT Al Kahfi Lebong standby setiap hari selama hari kerja. Solusi itu tepat karena memang ada siswa yang tidak mempunyai android mereka datang dan langsung bertanya kepada guru kelas karena berkomunikasi merupakan dasar interaksi antar manusia untuk memperoleh kesepakatan dan pemahaman yang bertujuan untuk mencapai suatu tujuan yang maksimal (Prajodi \& Afrila, 2021).

\section{4) Solusi mengatasi kurangnya kerjasama orang tua dan siswa}

Di SDIT Al Kahfi Lebong pihak orang tua yang sibuk dengan kepentinganya masing-masing dan tidak telaten mendampingi anak dalam proses pembelajaran jarak jauh ini membuat siswa yang harusnya belajar mereka bermain dengan teman sebaya. Pihak kepala sekolah dan guru kelas VI mempunyai solusi sendiri untuk mengatasi masalah tersebut yaitu dengan cara memberikan motivasi dan pemahaman kepada orang tua agar tetap mendampingi putra-putrinya belajar di rumah karena pengendalian dan pengawasan orang tua sangat penting pada saat pembelajaran daring seperti ini. Peran orang tua yang dimaksud dalam hal ini adalah orang yang bertanggung jawab dalam keluarga atau rumah tangga yang umumnya dalam kehidupan sehari-hari disebut ibu-bapak (Warsah, 2018b, 2020).

\section{5) Solusi mengatasi keterbatasan sarana dan prasarana}

Keterbatasan fasilitas sekolah seperti buku paket menjadi hambatan dalam proses pembelajaran. SDIT Al-Kahfi Lebong mengalami kurangnya buku paket dan membuat siswa menjadi terbatas untuk memilikinya atau membacanya. Pihak kepala sekolah memberikan solusi mengenai masalah ini yaitu dengan cara photocopy buku paket tersebut. Meskipun belum terlaksana namun solusi ini dipandang tepat agar siswa tetap terus belajar.

\section{B. Kesimpulan}

Berdasarkan hasil dan pembahasan di atas, maka dapat disimpulkan beberapa poin penting sebagai berikut: Pelaksanaan pembelajaran daring pada siswa kelas VI di SDIT Al-Kahfi Lebong tahun pelajaran 2019/2020 sudah berjalan dengan baik karena guru memberikan penugasan dan pemberian materi selama proses pembelajaran daring melalui android dengan memanfaatkan grup kelas VI. Sementara masalah yang dihadapi dalam proses pembelajaran daring di SDIT Al-Kahfi Lebong: masalah yang berkaitan dengan kompetensi guru, perbedaan tingkat pemahaman peserta didik, 
orang tua yang tidak memiliki android, kurangnya kerjasama orang tua dengan siswa dan keterbatasan sarana dan prasarana. Strategi kepala sekolah yang ditempuh untuk menyelesaikan permasalahan pembelajaran daring adalah mengutus guru untuk mengikuti seminar atau pelatihan tentang teknologi informasi dan belajar pada teman sebaya, memberi bimbingan atau pendampingan anak secara kelompok atau individual, memberi penyuluhan dan mengadakan pertemuan dengan wali murid mengenai pentingnya penggunaan android dalam proses pembelajaran dan memberikan pengertian tentang pentingnya kerjasama orang tua dalam mengawasi putra-putrinya belajar dari rumah.

\section{Daftar pustaka}

Abi Hamid, M., Ramadhani, R., Masrul, M., Juliana, J., Safitri, M., Munsarif, M., Jamaludin, J., \& Simarmata, J. (2020). Media pembelajaran. Yayasan Kita Menulis.

Ambarsari, R. Y. (2021). Evaluasi Pembelajaran Daring Selama Pandemi Covid-19 Di Kecamatan Bulukerto Wonogiri. Jurnal Mitra Swara Ganesha, 8(1), 2835.

Amini, A., \& Ginting, N. (2020). Otonomi Pendidikan di Masa Krisis Pandemi Covid-19 (Analisis Peran Kepala Sekolah). Al-Muaddib: Jurnal Ilmu-Ilmu Sosial Dan Keislaman, 5(2), 305-314.

Angdreani, V., Warsah, I., \& Karolina, A. (2020). Implementasi Metode Pembiasaan: Upaya penanaman nilai-nilai islami siswa SDN 08 Rejang Lebong. At-Ta'lim: Media Informasi Pendidikan Islam, 19(1), 1-21.

Atsani, K. L. G. M. Z. (2020). Transformasi media pembelajaran pada masa Pandemi COVID-19. Al-Hikmah: Jurnal Studi Islam, 1(1), 82-93.

Cholid, N. (2021). Menjadi Guru Profesional. CV Presisi Cipta Media.

Dewi, W. A. F. (2020). Dampak Covid-19 terhadap implementasi pembelajaran daring di Sekolah Dasar. Edukatif: Jurnal Ilmu Pendidikan, 2(1), 55-61.

Elisvi, J., Archanita, R., Wanto, D., \& Warsah, I. (2020). Analisis Pemanfaatan Media Pembelajaran Online di SMK IT Rabbi Radhiyya Masa Pandemi Covid-19. Al-Tarbawi Al-Haditsah: Jurnal Pendidikan Islam, 5(2), Article 2. https://doi.org/10.24235/tarbawi.v5i2.6721

Erdiyanto, E., Asha, L., Warsah, I., \& Hamengkubuwono, H. (2020). Manajemen Peningkatan Mutu Pendidikan di Madrasah Aliyah NegerI O2 Lebong, BENGKULU. Islamic Management: Jurnal Manajemen Pendidikan Islam, 3(02), 234-250. https://doi.org/10.30868/im.v3i2.840

Fathurahman, N. (2020). Inovasi Pembelajaran Daring Pada Masa Pandemi Covid-19. Prosiding Seminar Nasional Pendidikan FKIP, 3(1), 615-627.

Fatimah, D., Chan, F., \& Sofwan, M. (2021). Analisis pelaksanaan pembelajaran daring pada masa pandemi Covid-19 di sekolah dasar [PhD Thesis]. UNIVERSITAS JAMBI.

Fatmawati, Y. (2021). Problematika Pembelajaran Daring Anak Sekolah Dasar Disdiufadlunnafisbangsri. Tunas Nusantara, 3(1), 312-323. 
Hartono, H., \& Yusuf, Y. (2021). Tinjauan Molekuler dan Epidemiologi Mutasi pada Virus SARS-CoV-2. Bionature, 22(1).

Herlina, N. (2020). Manajemen Pembelajaran Daring Di Perguruan Tinggi Pada Masa Pandemi Covid-19. Journal Civics \& Social Studies, 4(2), 102-108.

Jamali, Y. (2019). Kompetensi Supervisi Kepala Sekolah Dalam Pengembangan Keprofesian Berkelanjutan. Jurnal Ilmiah Sustainable, 2(1).

Khairuddin, K. (2020). Kepemimpinan Kepala Sekolah Ditengah Pandemi Copid-19. Edukasi, 8(2), 171-183.

Kumaidi, K. (2018). Pengembangan Pendidikan Matematika: Visi Seorang Spesialis Penilaian Kelas.

Lestari, P. A. S., \& Gunawan, G. (2020). The impact of Covid-19 pandemic on learning implementation of primary and secondary school levels. Indonesian Journal of Elementary and Childhood Education, 1(2), 58-63.

Manurung, B., \& Sibuea, N. (2021). Perubahan model kebijakan pelayanan kepala sekolah di SMA Negeri 20 Medan di era COVID-19. Indonesian Journal of Educational Development, 2(1), 10-18.

Meliza, M., Wanto, D., \& Asha, L. (2020). Persepsi Masyarakat Sukaraja, Rejang Lebong Terhadap Edaran Menteri Agama Nomor: SE. 6. Tahun 2020 Mengenai Tata Cara beribadah Saat Pandemi. Manhaj: Jurnal Penelitian dan Pengabdian Masyarakat, $\quad 9(1), \quad 1-17$. https://doi.org/10.29300/mjppm.v9i1.3268

Miles, M. B., Huberman, M. A., \& Saldana, J. (2014). Drawing and verifying conclusions. Qualitative data analysis: A methods sourcebook.

Murfi, A., Fathurrochman, I., Atika, A., \& Jannana, N. S. (2020). Kepemimpinan sekolah dalam situasi krisis Covid-19 di Indonesia. MANAGERIA: Jurnal Manajemen Pendidikan Islam, 5(1), 119-136.

Nadeak, B., \& Juwita, C. P. (2020). Kepemimpinan kepala sekolah dalam menjaga tata kelola sekolah selama masa pandemi Covid-19. Jurnal Konseling Dan Pendidikan, 8(3), 207-216.

Nahdi, D. S., \& Jatisunda, M. G. (2020). Analisis literasi digital calon guru SD dalam pembelajaran berbasis virtual classroom di masa pandemi covid-19. Jurnal Cakrawala Pendas, 6(2), 116-123.

Nasution, M. I. P. (2016). Strategi pembelajaran efektif berbasis mobile learning pada sekolah dasar. IQRA': Jurnal Perpustakaan Dan Informasi, 10(1).

Pane, A., \& Dasopang, M. D. (2017). Belajar dan pembelajaran. Fitrah: Jurnal Kajian Ilmu-Ilmu Keislaman, 3(2), 333-352.

Prajodi, D., \& Afrila, D. (2021). Identifikasi Kesulitan Guru Dalam Pembelajaran Daring (Dalam Jaringan) di SMA DB 3 Kota Jambi Tahun Ajaran 2020/2021. ISTORIA: Jurnal Ilmiah Pendidikan Sejarah Universitas Batanghari, 5(1), 97-109.

Prsetyo, B., \& Jannah, L. M. (2019). Metode penelitian kuantitatif. 
Rahmawati, M., \& Suryadi, E. (2019). Guru sebagai fasilitator dan efektivitas belajar siswa. Jurnal Pendidikan Manajemen Perkantoran (JPManper), 4(1), 49-54.

Ramadhani, F. (2020). Penerapan Model Pembelajaran Project Based Learning (PJBL) Untuk Meningkatkan Hasil Belajar Ipa Pada Materi Bioteknologi Dan Produksi Pangan Dalam Pembelajaran Daring. Jurnal Pelita Pendidikan, 8(4).

Riley, S., Walters, C. E., Wang, H., Eales, O., Haw, D., Ainslie, K. E., Atchinson, C., Fronterre, C., Diggle, P. J., \& Page, A. J. (2021). REACT-1 round 12 report: Resurgence of SARS-CoV-2 infections in England associated with increased frequency of the Delta variant. MedRxiv.

Robinson, H., Broadbent, E., \& MacDonald, B. (2016). Group sessions with P aro in a nursing home: Structure, observations and interviews. Australasian Journal on Ageing, 35(2), 106-112.

Rozi, F., Nuzuar, Kusen, \& Warsah, I. (2020). Sinergitas Peran Komite Dan Kepala Madrasah Dalam Meningkat Mutu Pendidikan DI MAN 1 Lebong, Bengkulu: Indonesia. Jurnal Manajemen Pendidikan Islam Al-Idarah, 5(2), 59-66.

SALIM, W. A. (2021). Problematika Pembelajaran Daring Pada Siswa Kelas V SD Negeri 3 Cemeng Kecamatan Donorojo Kabupaten Pacitan Tahun 2020. JURNAL PENDIDIKAN DAN PEMBELAJARAN: Kajian Teori Dan Praktik Kependidikan, 2(1), 98-110.

Sanjaya, R. (2020). 21 Refleksi Pembelajaran Daring di Masa Darurat. SCU Knowledge Media.

Sekha, N. M. A. (2020). Problematika Pembelajaran Daring Pada Siswa Kelas IV MI Bustanul Mubtadin Kecamatan Suruh Kabupaten Semarang Tahun Pelajaran $2019 / 2020$.

Sudika, I. W. (2020). Kepemimpinan Kepala Sekolah Dasar Pada Era Revolusi Industri 4.0 dan Pandemi Covid 19. Edukasi: Jurnal Pendidikan Dasar, 1(2), $113-124$.

Suhartiningsih, S. (2021). Peningkatan Kinerja Guru dalam Pembuatan Video Pembelajaran Daring melalui Supervisi Individual SD Negeri Kemijen 01 Kota Semarang. Jurnal Inovasi Pembelajaran Di Sekolah, 2(1), 64-76.

Tamara, J., Sugiatni, S., Yanuarti, E., Warsah, I., \& Wanto, D. (2020). Strategi Pembelajaran Dosen Melalui Pemanfaatan Media Whatsapp di Masa Pandemi Covid-19. At-Ta'lim : Media Informasi Pendidikan Islam, 19(2), 351-373. https://doi.org/10.29300/attalim.v19i2.3372

Tanjung, R. (2021). Dampak Pandemi Covid 19 Terhadap Proses Pengajaran DI SD Negeri 118273 Mampang Kecamatan Kotapinang Kabupaten Labuhan Batu Selatan. Dirasatul Ibtidaiyah, 1(1), 98-110.

TARIGAN, G. S. (2019). Peningkatan Hasil Belajar Siswa Menggunakan Model Pembelajaran Make A Match Pada Mata Pelajaran Matematika di Kelas IV SD Negeri 043936 Merek Situnggaling Tahun Pelajaran 2018/2019 [PhD Thesis]. Universitas Quality.

Uyun, M., \& Warsah, I. (2021). Psikologi Pendidikan. Deepublish. 
Uyun, M., \& Warsah, I. (2021). IAIN Curup Students' Self-Endurance And Problems IN Online Learning During The Covid-19 Pandemic. Edukasi Islami: Jurnal Pendidikan Islam, 10(01), 395-412. https://doi.org/10.30868/ei.v10i01.1211

Warsah, I. (2018). Pendidikan Keimanan Sebagai Basis Kecerdasan Sosial Peserta Didik: Telaah Psikologi Islami. Psikis: Jurnal Psikologi Islami, 4(1), 1-16.

Warsah, I. (2018). Pendidikan Keluarga Muslim di Tengah Masyarakat Multi Agama: Antara Sikap Keagamaan dan Toleransi (Studi di Desa Suro Bali KepahiangBengkulu). Edukasia: Jurnal Penelitian Pendidikan Islam, 13(1), 1-24. https://doi.org/10.21043/edukasia.v13i1.2784

Warsah, I. (2020). Pendidikan Islam dalam Keluarga: Studi Psikologis dan Sosiologis Masyarakat Multi Agama Desa Suro Bali. Tunas Gemilang Press.

Warsah, I. (2021). Islamic Religious Teachers' Efforts To Motivate Students And Implement Effective Online Learning. Edukasi Islami: Jurnal Pendidikan Islam, 10(01), 383-394. https://doi.org/10.30868/ei.v10i01.1210

Warsah, I., \& Nuzuar, N. (2018). Analisis Inovasi Administrasi Guru dalam Meningkatkan Mutu Pembelajaran (Studi Man Rejang Lebong). Edukasi, 16(3), 294572.

Warsah, I., \& Uyun, M. (2019). Kepribadian Pendidik: Telaah Psikologi Islami. Psikis: Jurnal Psikologi Islami, 5(1), 62-73. https://doi.org/10.19109/Psikis.v5i1.3157

Wiguna, I. B. A. A. (2021). Kepemimpinan Kepala Sekolah PAUD Di Masa Pandemi Covid-19. Prosiding Seminar Nasional Institut Agama Hindu Negeri Tampung Penyang Palangka Raya, 1, 221-233.

Yessi, M. (2021). Pedagogical Content Knowledge (Pck) Dalam Pemilihan Media Pembelajaran Yang Relevan. Seminar Nasional Kimia Dan Pendidikan Kimia (SN-KPK), 12(0), 176-190. 